\section{PENERAPAN \\ PERMAINAN \\ TRADISIONAL \\ BERBASIS \\ MATEMATIKA}

\author{
Arfatin Nurrahmah*, Rita Ningsih \\ Pendidikan Matematika, Universitas \\ Indraprasta PGRI, Jakarta
}

\author{
Article history \\ Received : 24-05-2018 \\ Revised : 12-10-2018 \\ Accepted: 14-11-2018
}

\section{*Corresponding author}

Arfatin Nurrahmah

Email :

arfatinnurrahmah@gmail.com

\begin{abstract}
Abstraksi
Matematika memiliki peran yang penting sebagai aspek pembentukan sikap. Pembelajaran matematika melalui permainan tradisional dapat digunakan oleh guru dalam melaksanakan tugasnya untuk menyampaikan materi dan membantu pembentukan sikap peserta didiknya. Kegiatan pengabdian ini diharapkan mampu menumbuhkan sikap positif kepada siswa dalam pembelajaran dan dapat mengubah cara pandang siswa terhadap mata pelajaran matematika. Banyak permainan tradisional yang dapat dikaitkan dengan materi matematika. Diantaranya adalah congklak, engklek, dan bekel. Melalui pembelajaran dengan permainan tradisional, siswa diharapkan lebih bersemangat untuk belajar materi-materi matematika. Kegiatan pengabdian masyarakat ini dilaksanakan di SD Negeri Tengah 05 Pagi yang terletak di Jalan Pelita Raya RT.003/ RW. 09 Kampung Tengah, Jakarta Timur. Peserta dalam kegiatan pengabdian masyarakat ini adalah guru dan siswa SDN Tengah 05 Pagi. Metode pelaksanaan kegiatan ini antara lain: observasi, diskusi, dokumentasi, demonstrasi, dan praktek. Kegiatan dilakukan dengan berbagi informasi dengan guru matematika mengenai alternatif penyampaian dan penyajian materi yang menarik dan menyenangkan, salah satunya dengan menggunakan media permainan tradisional yang berbasis matematika. Setelah itu menjelaskan tentang alur dan cara menggunakan media yang disediakan dan konsep matematika apa saja yang sesuai dengan permainan tersebut. Selain untuk meningkatkan motivasi anak dalam belajar matematika, manfaat permainan tradisional antara lain dapat mengembangkan kecerdasan intelektual, melatih kemampuan motorik, mengembangkan kecerdasan emosi serta meningkatkan kemampuan bersosialisasi.
\end{abstract}

Kata Kunci: Matematika, Permainan Tradisional

\begin{abstract}
Mathematics has an important role as aspects of the formation of attitude. Learning mathematics through games traditionally can be used by teachers in carrying out his duty to deliver the material and help the formation of attitudes of the participants his protégé. The activities of this devotion is expected to foster a positive attitude to the students in learning and can change the way the student's point of view towards mathematical subjects. Many traditional games that can be associated with a matter of mathematics. Among them are congkak, engklek, and the bead seats. Through learning with traditional games, students are expected to be more eager to learn math materials. This outreach activity is carried out in SD Negeri Middle 05 Morning located at Jalan Pelita Kingdom RT. 003/RW. 09 Kampung Tengah, East Jakarta. Participants in the activities of the public service this is the teachers and students of SDN 05 Middle morning. The method of implementation of these activities include: observation, documentation, discussion, demonstration, and practice. Activities done with information sharing with teachers of mathematics on alternative delivery and presentation of material that is interesting and fun, one of them using traditional games media-based mathematics. After that describes the media and how to use the Groove provided and any math concepts that fit with the game. In addition to increasing the motivation of children in learning math, the benefits of traditional game among others can develop intellectual intelligence, train motor capabilities, developing emotional intelligence as well as enhance the ability socialize
\end{abstract}

Keywords: Mathematics, Traditional Games 


\section{PENDAHULUAN}

Pada jaman dahulu, anak laki-laki dan perempuan sangat menggemari dan sering memainkan permainan tradisional. Seiring berjalannya waktu, perkembangan teknologi di era modern yang begitu cepat seperti sekarang ini menjadikan permainan tradisional mulai ditinggalkan dan dilupakan. Terlebih di kota besar seperti di Jakarta, Surabaya, dan sebagainya. Anak-anak lebih memilih permainan modern, seperti play station, gadget, dan alat digital lainnya dibanding permainan tradisional seperti kelereng, engklek, bekel, dakon atau congklak, dan sebagainya. Penggunaan yang praktis dan tidak memerlukan banyak ruang menjadikan anak-anak lebih suka memainkan permainan modern dibandingkan permainan tradisonal. Padahal, tak dapat dipungkiri bahwa permainan modern yang serba canggih membawa dampak buruk karena menjadikan anak-anak lebih bersifat individualistis. Anak-anak cenderung menjadi anti sosial dan berkurangnya rasa tenggang rasa antar sesama teman.

Permainan tradisional dapat membuat anak menjadi lebih kreatif dan bekerjasama untuk menjadi pemenang. Cara permainan yang melibatkan dua orang atau lebih dapat menumbuhkan sikap sosial pada diri anak. Meskipun demikian, kebanyakan orang tua malah sering merasa khawatir terhadap kegiatan bermain anak yang seperti ini. Orang tua lebih suka membiarkan anaknya menikmati permainan-permainan modern di kamarnya daripada mengijinkan anaknya untuk bermain bersama teman-temannya di luar rumah. Padahal jika dilihat dari segi positif, kegiatan bermain anak tersebut dapat dijadikan kegiatan belajar yang menyenangkan sejalan dengan tumbuh kembang anak.

Para ahli pendidikan berpendapat bahwa permainan memiliki banyak manfaat bagi anak. Parten (dalam (Sujiono, 2009)) memandang kegiatan bermain sebagai sarana sosialisasi. Melalui permainan, anak diharapkan mampu menemukan dan mengeksplorasi sesuatu hal yang baru, menujukkan dan mengekspresikan perasaan, dan belajar dengan cara yang lebih menyenangkan. Untuk mengembangkan semua kemampuannya, salah satu cara yang baik adalah dengan bermain, karena melalui bermain, seorang anak akan mendapatkan informasi dan memproses informasi tersebut menjadi hal baru melalui keterampilan yang ada. Pada dasarnya, bermainan melalui pendekatan permainan yang kreatif memiliki tujuan yang utama yaitu untuk mengoptoimalkan perkembangan anak usia dini dan kanak-kanak.
Interaksi belajar anak dapat dilakukan dan diintegrasikan dengan lingkungan bermain anak. Untuk itu, permainan yang berkualitas perlu dipilih agar proses belajar anak dapat berjalan dengan baik (Sujiono, 2009). Banyak permainan tradisional yang aman dan berkualitas untuk dipilih sebagai sarana belajar anak. Permainan tradisional seperti congklak, engklek, dan bekel merupakan permainan yang dapat dikaitkan dengan materi pelajaran, terutama dalam pelajaran matematika.

Matematika memiliki peran yang penting sebagai aspek pembentukan sikap (Daryanto, 2010). Masalah utama dalam pendidikan matematika di Indonesia adalah rendahnya prestasi belajar siswa di sekolah. Dalam konteks pendidikan matematika, prestasi belajar yang dimaksud tidak hanya pada kemampuan pada kemampuan mengerti matematika sebagai pengetahuan (kognitif) melainkan juga pada aspek sikap dan keterampilan (Ningsih \& Nurrahmah, 2016). Untuk itu pembelajaran matematika juga perlu dikembangkan melalui permainan-permainan tradisional. Pembelajaran matematika melalui permainan tradisional dapat digunakan oleh guru dalam melaksanakan tugasnya untuk menyampaikan materi dan membantu pembentukan sikap peserta didiknya. Kondisi pembelajaran matematika yang terjadi di kebanyakan sekolah saat ini masih belum banyak menggunakan sarana permainan. Berdasarkan hasil pengamatan dan informasi yang diperoleh, pembelajaran matematika di kelas masih menggunakan metode konvensional. Guru berperan sebagai pusat pembelajaran. Siswa kurang terlibat secara aktif selama pembelajaran. Kondisi ini menjadikan pembelajaran matematika kurang menarik di mata siswa. Akibatnya, siswa kurang bersemangat selama proses pembelajaran.

Kebanyakan siswa juga beranggapan bahwa matematika merupakan mata pelajaran yang sulit. Hal ini menyebabkan siswa sulit untuk memahami dan mengingat materi yang dipelajari. Pada umumnya matematika dianggap sebagai hal yang menakutkan bagi siswa, beberapa penyebabnya adalah pendekatan pembelajaran yang kurang sesuai dengan kondisi dan karakteristik siswa (Oktaviyanthi, Safaah, \& Agus, 2017). Setiap guru memerlukan model, metode, pendekatan, serta media yang tepat dalam kegiatan pembelajaran agar kegiatan dapat berlangsung efektif. (Nurrahmah \& Suhendar, 2017). Idealnya dalam mengajarkan matematika, seorang guru haruslah memperhatikan perkembangan mental siswanya. Salah satu ciri dari anak pada usia sekolah dasar berinteraksi dengan lingkungan sekitar melalui 
bermain, karena anak pada usia ini mempunyai energy yang tak terbatas. Guru dapat mengambil keuntungan dari aktivitas permainan siswa sehingga memungkinkan siswa belajar dari yang dikenal ke yang tidak diketahui dan dari konkrit ke yang abstrak. Dengan menggunakan aktivitas budaya lokal dan permainan dalam proses belajar mengajar matematika, siswa akan termotivasi sehingga siswa melihat matematika sebagai kegiatan yang populer dan bersejarah (Muzdalipah \& Yulianto, 2015). Untuk itu, permainan tradisional dapat digunakan sebagai sarana belajar matematika sekaligus menumbuhkan jiwa nasionalisme dalam diri siswa.

Kegiatan ini diharapkan mampu menumbuhkan sikap positif kepada siswa dalam pembelajaran dan dapat mengubah cara pandang siswa terhadap mata pelajaran matematika. Melalui pembelajaran dengan permainan tradisional, siswa diharapkan lebih bersemangat untuk belajar materi-materi matematika. Kegiatan ini juga diharapkan dapat menjadi referensi guru untuk mengembangkan pembelajaran lain yang lebih inovatif dan kreatif,juga diharapkan dapat menjadi alternatif solusi bagi guru dalam mengatasi masalah-masalah selama proses pembelajaran.

\section{METODE PELAKSANAAN}

Kegiatan pengabdian masyarakat ini dilaksanakan di SD Negeri Tengah 05 Pagi yang terletak di Jalan Pelita Raya RT.003/ RW. 09 Kampung Tengah, Jakarta Timur. Peserta dalam kegiatan pengabdian masyarakat ini adalah guru dan siswa SDN Tengah 05 Pagi. Pemilihan sekolah didasarkan pada hasil observasi pembelajaran matematika di SD tersebut masih menggunakan model konvensional. Kegiatan akan dilaksanakan dalam jangka waktu tiga bulan.

Metode pelaksanaan kegiatan ini adalah sebagai berikut: (1) Observasi: metode observasi dilakukan untuk mendapatkan informasi mengenai pembelajaran matematika yang biasa dilakukan di SDN Tengah 05 Pagi. Dengan metode ini diperoleh data berupa keadaan sekolah, suasana kelas pada saat pembelajaran, metode pembelajaran yang digunakan guru, sikap siswa terhadap pembelajaran, serta permasalahan-permasalahan mengenai pembelajaran matematika di sekolah. (2) Diskusi: diskusi dilakukan untuk membahas mengenai solusi dari permasalahan-permasalahan yang muncul dalam pembelajaran matematika. Diskusi ini terjadi antara Tim Abdimas dengan mitra kegiatan, yaitu Kepala Sekolah dan guru matematika SDN Tengah 05 Pagi. Dari diskusi ini diperoleh solusi untuk permasalahan pembelajaran matematika, yaitu penggunaan permainan tradisional dalam pembelajaran matematika; (3) Metode Dokumentasi: metode dokumentasi dalam kegiatan ini dilakukan untuk memperoleh data-data fisik yang berhubungan dengan pembelajaran matematika, seperti nilai ulangan siswa dan rencana pelaksanaan pembelajaran; (4) Demonstrasi: demonstrasi dilakukan untuk memberikan contoh penggunaan permainan tradisional kepada guru. Demonstrasi juga dilakukan dalam perancangan pembelajaran dengan permainan tradisional; (6) Praktek: metode praktek merupakan metode inti dari kegiatan ini. Metode ini dilaksanakan pada saat pembelajaran, yaitu guru memperkenalkan permainan tradisional berbasis matematik kepada peserta didik.

\section{PEMBAHASAN \\ Implementasi Kegiatan}

Peserta kegiatan terdiri atas guru-guru matematika dan siswa kelas VI SD Tengah 05 Pagi. Tim pelaksana memulai kegiatan dengan berbagi informasi dengan guru matematika mengenai alternatif penyampaian dan penyajian materi yang menarik dan menyenangkan, salah satunya dengan menggunakan media permainan tradisional yang berbasis matematika. Setelah itu menjelaskan tentang alur dan cara menggunakan media yang disediakan dan konsep matematika apa saja yang sesuai dengan permainan tersebut. Selain itu guru juga dibimbing dalam pembuatan RPP berbasis permainan tradisional matematika agar pembelajaran yang dilakukan bervariasi dan menyenangkan.

Pada kegiatan selanjutnya, tim pelaksana memberikan kesempatan kepada guru untuk mensimulasikan permainan tersebut kepada siswa kelas VI di kelas maupun di lapangan. Pemilihan kelas disesuaikan dengan materi yang sudah diajarkan serta kesesuaian dengan permainan tradisional yang dilakukan, yaitu dacon (congklak), bekel, dan angklik. Siswa dibagi menjadi 6 kelompok dan masing-masing kelompok bermain tiga permainan tersebut secara bergiliran. Masingmasing permainan didampingi oleh 1 guru dan 1 tim abdimas. Guru menjelaskan aturan permainan, memperhatikan serta memberikan penjelasan sesuai dengan konsep matematika yang ada dalam permainan. Siswa terlihat antusias dan semangat dalam bermain. matematika sambil bermain.

Kaitan Permainan Tradisional dengan Matematika Banyak permainan tradisional yang dapat dikaitkan dengan materi matematika. Di antaranya adalah congklak, engklek, dan bekel. Berikut deskripsi 
permainan tradisional yang mengandung unsurunsur matematis.

\section{(1) Congklak}

Congklak merupakan permainan yang dilakukan oleh dua orang yang saling berhadapan menggunakan alat bantu papan congklak yang disebut dengan dakon.

a) Tata Cara

Dalam permainan congklak terdapat tujuh lubang lawan dan tujuh lubang kawan dengan setiap lubang terdiri dari tujuh buah batu atau kerang. Semakin banyak batu yang dipilih maka akan semakin banyak lubang yang diisi, termasuk peluang lubang induk terisi lebih besar. Artinya dalam memainkan congklak, anak-anak bisa membedakan mana lubang yang lebih banyak dengan yang sedikit. Untuk bisa membedakan mana lubang yang memiliki batu lebih banyak, pemain harus melihat secara kasat mata dan menghitung jumlah batu jika ada lubang yang terlihat sama banyaknya.

b) Desain Pembelajaran

Desain pembelajaran melalui permainan congklak bisa diterapkan pada siswa jenjang SD kelas IV, yaitu pada materi operasi hitung. Desain pembelajaran ini cenderung mengarahkan siswa untuk lebih memahami bahwa matematika merupakan bagian dari kehidupan yang akan selalu ada dalam setiap aktivitas yang dilakukan manusia. Oleh karena itu, pembelajaran didesain dalam bentuk pendidikan matematika realistik dengan menggunakan alat peraga yang dimainkan siswa secara langsung.

Pada proses berjalannya aktivitas belajar siswa, guru menggali beberapa konsep matematika melalui beberapa pertanyaan yang nantinya dapat terlihat bagaimana keterampilan siswa memahami operasi penjumlahan dan pengurangan. Selanjutnya guru menanyakan pertanyaan-pertanyaan, seperti "awalnya berapa biji congklak yang kalian punya?", "berapa banyak biji congklak yang ada dalam satu lubang?", dan sebagainya.

c) Konsep Matematika dalam Permainan Congklak Dalam permainan congklak, siswa mempelajari konsep penjumlahan, pengurangan, pembagian, dan perkalian. Ketika memulai permainan, siswa akan mengambil biji dari salah satu lubang yang menjadi salah satu wilayahnya, kemudian biji tersebut disebarkan satu persatu kepada lubang-lubang yang lain sampai habis. Sambil bermain, guru dapat mengingatkan kepada siswa bahwa yang dilakukan tersebut berhubungan dengan konsep matematika, antara lain penjumlahan, pengurangan, penjumlahan, perkalian, serta pembagian.

Adapun konsep dari perkalian adalah penjumlahan yang berulang-ulang. Guru dapat mengajarkan kepada siswa bahwa untuk menghasilkan operasi hitung perkalian, dapat dilakukan dengan menjumlahkan secara berulang suatu angka yang sama. Misalnya dalam permainan congklak, ada tujuh buah lubang, dimana setiap lubang berisikan 7 biji. Jadi, sebagai awalan, masing-masing pemain memiliki 35 biji congklak yang didapatkan dari penjumlahan $5+5+5+5+5+5+5=35$. Artinya angka tujuh dijumlahkan sebanyak lima kali hasilnya adalah 35. Maka perkaliannya dituliskan $7 \times 5=35$.

Begitupun untuk konsep pembagian yang merupakan pengurangan suatu bilangan dengan bilangan lain secara berulang-ulang hingga mendapatkan bilangan nol. Misalnya siswa memiliki 35 biji yang akan disebar ke tujuh lubang. Maka dapat dituliskan dengan : 35 - 7 7- 7- 7-7=0, artinya bilangan 35 dikurangi 7 sebanyak 5 kali, maka dapat dituliskan ke konsep pembagian, yaitu $35: 7=5$ (tiga puluh lima dibagi tujuh sama dengan lima

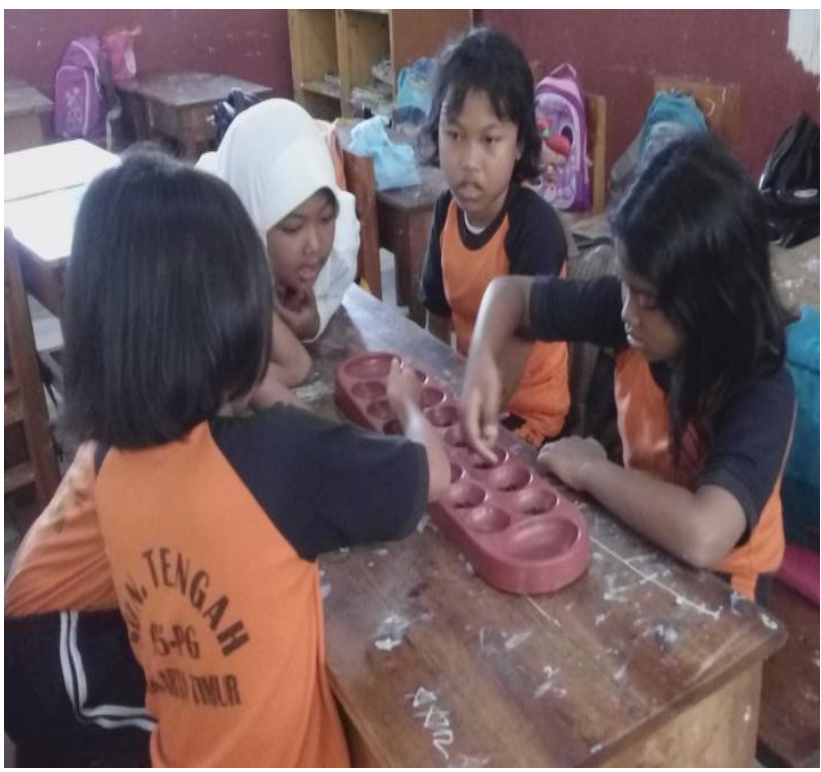

Gambar 1. Siswa bermain congklak

(2) Engklek

Di adat Sunda, permainan ini lebih sering dipanggil pecle, tetapi masyarakat pada umumnya 
memanggil permainan ini dengan sebutan engklek. Ada banyak macam sketsa yang biasa digunakan anak-anak. Sketsa digambarkan dengan garis pola persegi maupun persegi panjang, dan setengah lingkaran.

a) Tata Cara

Dalam permainan engklek diperlukan gacok atau sejenis koin yang terbuat dari batu atau pecahan genting. Gacok biasanya berbentuk lingkaran atau persegi. Di sini terlihat bahwa permainan ini erat hubungannya dengan sifatsifat geometri. Bentuk lintasan permainan merupakan bangun geometri yang memiliki simetri lipat. Kondisi ini menambah dukungan bahwa mereka akrab dengan geometri. Bahkan satu jenis desain dari lintasan pecle yang digunakan mirip dengan bentuk jari- jaring balok. Ini menunjukkan bahwa sangat banyak potensi matematika yang bisa dikembangkan dalam permainan ini.

Permainan ini dapat dilakukan secara berkelompok dengan banyaknya pemain antara dua hingga sepuluh orang. Adapun tata cara permainan engklek antara lain.

1) Menggambar arena permainan dengan menggunakan kapur

2) Untuk alat bermain, dapat menggunakan pecahan genting yang biasa disebut gancok, atau alau apapun yang mudah untuk dilemparkan

3) Urutan pemain dapat dilakukan dengan gambreng (jika lebih dari dua pemain) dan suit (jika dua pemain)

4) Permainan dimulain degan urutan Pemain pertama yang terlebih dahulu melempar gacok pada kotak nomor 1

5) Sesudah itu pemain pertama melewati kotak 1 dengan cara engkle(menggunakan salah satu kakinya) untuk menuju kotak nomor 2, 3, 4, dan seterusnya

6) Setelah sampai di kotak 7 dan 8, pemain berputar kembali menuju kotak 1 untuk menggambil gacok dan melompati kotak nomor 1 kembali pada posisi awal dan seterusnya.

b) Desain Pembelajaran

Pada permainan engklek, siswa dapat mempelajari konsep geometri dengan mendeskripsikan bentuk bangun datar yang sudah dipelajari, antara lain persegi, persegi panjang dan setengah lingkaran. Pendeskripsian ini dilakukan dengan menggambarkan arena bermain engklek yang tersusun dari bebepa bangun datar tersebut. Konsep lain yang dapat dipelajari siswa dari permainan ini adalah estimasi (perkiraan), dimana konsep estimasi ini dapat dilihat ketika siswa melemparkan gancoknya. Jika tepat di kotak (tidak keluar garis) maka anak tersebut dapat memperkirakan dengan baik posisi gancok yang tepat. Konsep berikutnya ialah konsep ukuran, dimana siswa dapat membedakan ukuran panjang, pendek, besar, kecil, dan luas.

c) Konsep Matematika pada Permainan Engklek Permainan engklek merupakan salah satu jenis permainan tradisional yang dapat melatih kemampuan siswa untuk mengenal bentuk bangun datar. Kemampuan siswa dapat diamati pada saat kegiatan bermain, apakah permainan sudah berjalan sesuai dengan aturan yang sudah ditetapkan sebelumnya oleh guru, antara lain seperti pada waktu meletakkan kaki pada angka, apakah menyentuh garis atau tidak. Selain itu, penguasaan konsep geometri yang diamati saat bermain adalah kemampuan anak dalam membedakan antara bentuk persegi, persegi panjang, dan setengah lingkaran serta mengestimasi lemparan dan lompatan yang dilakukan.

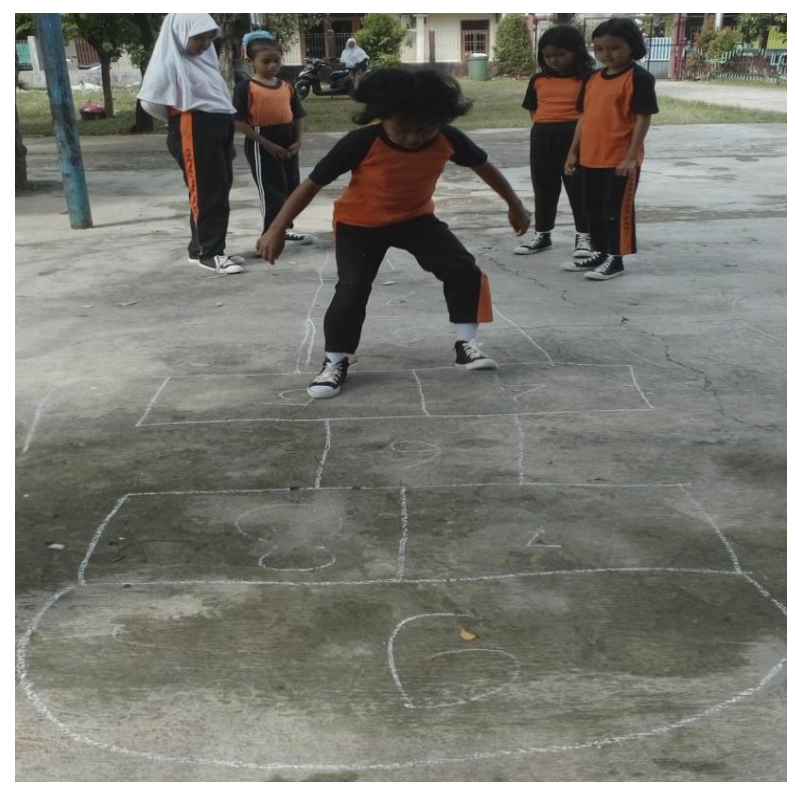

Gambar 2. Siswa bermain englek

(3) Bekel

Bekel adalah permainan tradisional yang sering dimainkan oleh anak perempuan. Biasanya dimainkan oleh dua sampai sepuluh orang secara bergantian. Alat yang digunakan adalah bola bekel dan biji bekel. Saat bermain bekel, siswa akan 
mempelajari konsep berhitung, menjumlah, mengurangi,membagi serta mengalikan.

\section{a) Tata Cara}

Pemain melempar bola bekel dan biji bekel secara bergantian pada satu kali lemparan dan kemudian menangkap kembali bola bekelnya setelah memantul ke tanah/ lantai. Saat melempar bola bekel, pemain mengambil satu persatu biji bekel dan segera menangkap bola bekel, seterusnya sampai semua biji bekel terambil kemudian dilemparkan kembali. Selanjutnya pemain mengambil dua biji bekel, tiga biji bekel, sampai seterusnya (maksimal 6). Permainan akan selesai jika biji bekel telah habis. Pemain harus bergantian jika bola tidak memantul satu kali distiap pelemparan, biji terlempar, atau bola tidak dapat ditangkap kembali saat dilemparkan.

b) Desain Pembelajaran

Pada permainan bekel, siswa dapat mempelajari konsep bangun ruang sederhana, penjumlahan, pengurangan, perkalian dan pembagian

c) Konsep matematika dalam permainan bekel Konsep matematika pada permainan bekel hampir sama dengan permainan congklak, antara lain, konsep penjumlahan dilakukan saat pemain ingin mengambil biji yang sudah disebarkan terebih dahulu. Misalnya pemain ingin mengambil biji satu persatu, maka konsep penjumlahan yang dilakukan adalah $1+1+1+$ $1+1+1=6$, atau $2+2+2=6$ dan $3+3=6$.

Konsep pengurangan dapat dipelajari setiap kali pemain mengambil satu persatu atau dua-dua biji bekel di lantai, misal saat biji bekel disebarkan, pemain dapat mengambil biji bekel satu persatu, yaitu enam di ambil satu, diambil satu, diambil satu jadi sisa empat biji bekel. 6 - 1 - $1=4$, kemudian emapt biji berikutnya ingin diambil dua, sehingga $4-2-2=0$, dan sebagaiya.

Adapun konsep perkalian yang terjadi saat permainan bekel adalah ketika pemain mengambil satu per satu biji bekel, dimana banyaknya biji bekel saat pengambilan dikali dengan banyaknya proses pengambilan. Jika pemain telah menyebarkan enam biji bekel ke lantai dan kemudian ingin diambil kembali, dengan melemparkan satu kali bola ke atas, pemain dapat mengambil keenam biji tersebut dengan beberapa pilihan. Jika ingin mengambil 2 biji pada setiap pengambilan, maka pemain tersebut butuh tiga kali pengambilan. Dapat dituliskan $3 \times 2=2+2+2=6$, artinya, dua biji bekel diambil sebanyak tiga kali tanpa pengembalian. Atau pilihan lain, jika pemain ingin mengambil tiga biji bekel dengan dua kali pengambilan, maka dapat dituliskan $2 \times 3=3+$ 3 , yang artinya, tiga biji bekel diambil sebanyak dua kali tanpa pengembalian.

Pada permainan bekel, konsep pembagian terjadi ketika pemain akan mengambil kembali biji yang sudah tersebar di lantai. Hampir mirip dengan konsep pengurangan, salah satu contoh pada pembagian, yaitu untuk mengambil sembilan biji bekel, dapat dibagi tiga biji bekel disetiap pengambilan. Dapat ditulis : 9 : 3 = (artinya terdapat sembilan biji bekel, diambil 3 biji pada setiap pengambilan tanpa pengembalian, sehingga didapatkan 3 kali pengambilan, dan sebagainya.

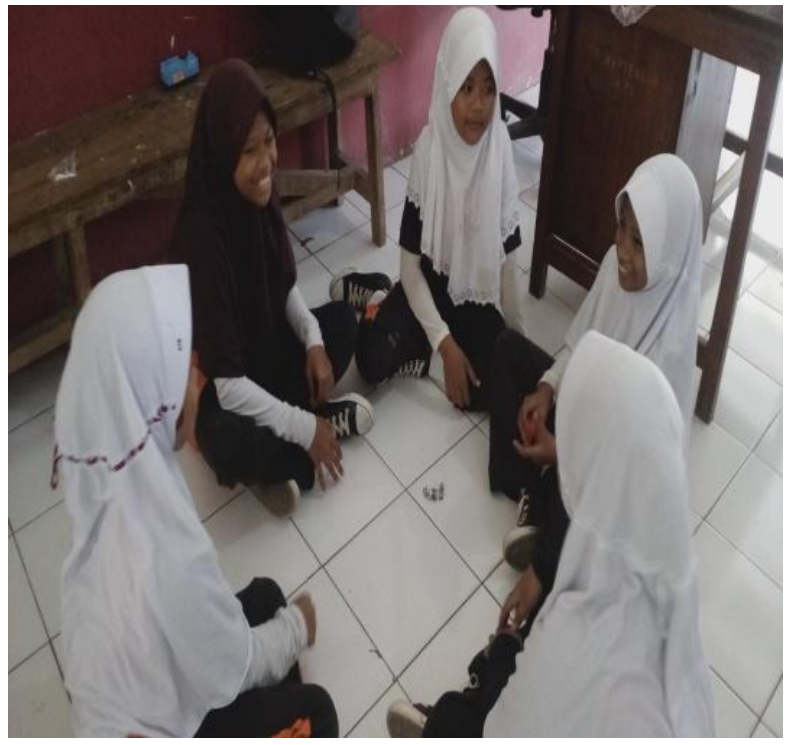

Gambar 3. Siswa bermain bekel

\section{Pembahasan Hasil Kegiatan}

SD Negeri Tengah 05 Pagi merupakan lembaga pendidikan dasar formal yang memiliki karakteristik siswa yang beragam. Hasil observasi dan wawancara terhadap guru diperoleh bahwa pembelajaran matematika masih menerapkan metode ceramah. Hal ini dikarenakan pembelajaran dengan metode ceramah lebih mudah dan tidak perlu mengeluarkan waktu serta biaya banyak. Penggunaan metode ceramah ini membuat guru lebih banyak menjelaskan materi sehingga siswa kurang terlibat aktif dalam proses pembelajaran. Suasana pembelajaran yang monoton dan "itu-itu saja" mengakibatkan siswa kurang menyukai pelajaran matematika sehingga 
terkadang hasil belajar yang didapatkan siswa masih juga belum memenuhi kriteria yang ditetapkan sekolah.

Berdasarkan hasil wawancara dengan guru, dikemukakan juga bahwa kesulitan yang dialami siswa saat mempelajari pembagian, sehingga hasil belajar yang didapatkan masih belum memenuhi target yang diinginkan. Selain itu, dari hasil pengamatan tim, diperlukan adanya variasi pembelajaran agar siswa tidak cepat bosan, misalnya dengan menggunakan media belajar. Sehingga langkah pertama yang tim lakukan adalah berbagi informasi kepada guru-guru matematika mengenai inovasi pembelajaran, khususnya penerapan konsep matematika menggunakan permainan tradisional.

Selain dalam pembelajaran matematika, sikap positif siswa dapat dikembangkan melalui permainan tradisional. Manfaat tersebut didapatkan karena siswa berinteraksi secara langsung dengan lingkungan. Adapun sikap postif yang dapat ditumbuhkan melalui permainan tradiional antara lain.

a. Kecerdasan intelektual pada anak yang semakin berkembang, salah satu contohnya di permainan dakon. Permainan tradisional ini merangsang otak kiri siswa dan melatih siswa menggunakan strategi agar dapat menggumpulkan biji lebih banyak dari lawan.

b. Kecerdasan emosi pada anak yang semakin terlatih, contohnya dapat terlihat ketika proses permainan berlangsung, mulai dari menentukan giliran bermain dan dilatih untuk sabar dan menerima kekalahan.

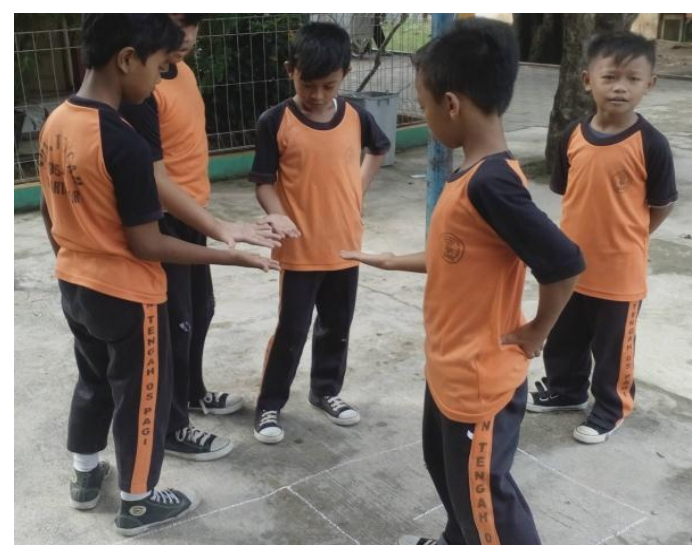

Gambar 4. Siswa melakukan gambreng untuk menentukan giliran

c. Kemampuan bersosialisasi, contohnya dalam setiap permainan dilakukan secara berkelompok. Hal ini dilakukan untuk memberikan kesempatan pada siswa untuk bersosialisasi, dan berkoordinasi antar kelompok. Selain kebersamaan, siswa juga dituntutuntuk dapat mentaati peraturan yang sudah ditetapkan, solidaritas ketika bermain, dan , sabar menunggu giliran.

d. Kemampuan motorik akan semakin terlatih, contohnya dalam permainan engklek siswa harus menyeimbangkan tubuhnya untuk melakukan loncatan yang baik agar tidak mengenai garis. Hal ini baik dilakukan untuk metabolism anak sehingga kemampuan motoric anak semakin terlatih.

\section{KESIMPULAN}

Kegiatan pengabdian masyarakat ini dirasa telah memberi kontribusi positif sebagai upaya untuk menciptakan hasil belajar yang optimal dan menciptakan pembelajaran matematika yang bermakna. Pembelajaran yang dilakukan melaui permainan tradisional dapat memotivasi siswa untuk menyenangi matematika. Selain untuk memudahkan siswa memahami materi pelajaran matematika terutama konsep perkalian dan pembagian, permainan tradisional juga memiliki banyak manfaat yang baik bagi perkembangan fisik dan emosi anak, antara lain dapat mengembangkan kecerdasan intelektual kecerdasan emosi, melatih kemampuan motorik dan meningkatkan kemampuan bersosialisasi dengan teman, guru, maupun lingkungan sekitar.

Adapun saran untuk kegiatan pengabdian ini, adalah Guru harus selalu meningkatkan keaktifan dan motivasi belajar matematika siswa agar hasil belajar yang didapatkan sesuai dengan kompetensi yang ingin dicapai, Guru hendaknya menerapakan model pembelajaran yang inovatif dan menggunakan strategi, model dan media pembelajaran yang mudah dibuat agar pembelajaran lebih menyenangkan bagi siswa. Sebagai upaya untuk meningkatkan kualitas pembelajaran, Dinas Pendidikan, LPMP, Perguruan Tinggi, sebagai pihak terkait perlu memberikan perhatian khusus dengan mengadakan kegiatan pelatihan yang serupa secara berkesinambungan dan intensif.

\section{DAFTAR PUSTAKA}

Daryanto. 2010. Media pembelajaran: Peranannya sangat penting dalam mencapai tujuan pembelajaran. Yogyakarta: Gaya Media.

Muzdalipah, I., \& Yulianto, E. 2015. Pengembangan desain pembelajaran matematika untuk siswa SD berbasis aktivitas budaya dan permainan tradisional masyarakat Kampung Naga. Jurnal Siliwangi Seri 
Pendidikan, 1 (1), 63-74.

Ningsih, Rita dan Nurrahmah, Arfatin. 2016. Pengaruh Kemandirian Belajar da Perhatian Orang Tua Terhadap Prestasi Belajar Marematika. Jurnal Formatif 6(1): 73-84.

Nurrahmah, Arfatin dan Suhendar,A.M. 2017. Peningkatan Hasil Belajar Matematika dengan Menggunakan LKS dan KKS. JKPM (Jurnal Kajian Pendidikan Matematika) Vol. 3, No. 1. 1-10.

Oktaviyanthi, R., Safaah, E., \& Agus, R. N. (2017). Pemberdayaan Keterampilan Guru Matematika dalam Menyusun Bahan Ajar Berbantuan Mathematics Education Software. Wikrama Parahita: Jurnal Pengabdian Masyarakat, 1 (1), 19-24.

Sujiono, Y. N. 2009. Konsep dasar pendidikan anak usia dini. Jakarta: PT indeks. 